\title{
Pemberdayaan Usaha Ekonomi Produktif Bagi Masyarakat Di Kecamatan Ploso Kabupaten Jombang
}

\author{
Nuri Purwanto \\ nuri.stiedw@gmail.com \\ Chusnul Rofiah \\ chusnulrofiah@yahoo.com \\ STIE PGRI Dewantara Jombang
}

Diserahkan: 25 Pebruari 2017, Disetujui: 15 Mei 2017

\begin{abstract}
Abstrak
Desa Pandan Blole yang terletak di Kecamatan Ploso kabupaten Jombang terkenal akan hasil produksinya berupa labu kuning (waluh) atau nama latinnya cucurbita moschata. Selama ini, hasil pertanian yang melimpah tersebut hanya dijual sebagai buah atau sayur tanpa diolah menjadi produk bernilai tambah lebih. Karena itu, tim penulis melakukan berbagai kegiatan pendampingan sabagai upaya peningkatan ekonomi masyarakat Desa Pandan Blole, melalui diversifikasi produk makanan berbahan dasar labu kuning. Kegiatan pelatihan dan pendampingan juga dilengkapi dengan pelatihan manajemen usaha, pencatatan keuangan hingga proses pemasaran. Dari hasil kegiatan, masyarakat desa Pandan Blole telah mampu menciptakan produk makanan ringan hingga kue berbahan dasar labu kuning dan mampu memasarkan hingga keluar wilayah Pandan Blole.
\end{abstract}

\begin{abstract}
Pandan Blole village located in Ploso district of Jombang district is famous for its production of pumpkin (waluh) or latinnya name cucurbita moschata. During this time, the abundant agricultural products are only sold as fruit or vegetables without being processed into more value-added products. Therefore, the authors team perform various assistance activities as an effort to improve the economic community Pandan Blole Village, through the diversification of food products made from pumpkin. Training and mentoring activities are also equipped with business management training, financial recording and marketing process. From the results of the activity, the people of Pandan Blole village have been able to create snack foods until yellow pumpkin cake and able to market until out of Pandan Blole region.
\end{abstract}

\section{A. PENDAHULUAN \\ 1. Latar Belakang}

Pemberdayaan merupakan suatu konsep untuk memberikan tanggungjawab yang lebih besar kepada orang-orang tentang bagaimana melakukan pekerjaan. Pemberdayaan akan berhasil jika dilakukan oleh pengusaha, pemimpin dan kelompok yang dilakukan secara terstruktur dengan membangun budaya kerja yang baik. Konsep pemberdayaan terkait dengan pengertian pembangunan masyatakat dan pembangunan yang bertumpu pada masyarakat.

Program-program pemberdayaan sumberdaya manusia telah dilakukan pemerintah. Hal ini sejalan dengan tujuan pembangunan Indonesia yaitu membangun manusia Indonesia seutuhnya, maka pembangunan harus merupakan perubahan sosial yang tidak hanya terjadi pada taraf kehidupan masyarakat belaka tetapi juga pada peranan unsur-unsur didalamnya. Pembangunan menempatkan manusia sebagai subyek pembangunan. Pemberdayaan masyarakat dalam penanggulangan kemiskinan menjadi komitmen bersama antara pemerintah pusat dengan pemerintah daerah. 
Kemiskinan merupakan masalah pembangunan kesejahteraan sosial yang berkaitan dengan berbagai bidang pembangunan lainnya yang ditandai oleh pengangguran, keterbelakangan, dan ketidakberdayaan. Oleh karena itu, kemiskinan terutama yang diderita oleh kaum miskin merupakan masalah pokok nasional yang penanggulanggannya tidak dapat ditunda lagi dan harus menjadi prioritas utama dalam pelaksanaan pembangunan kesejahteraan sosial. Penanganan kaum miskin tidaklah mudah, karena kaum miskin telah mengalami masalah kemiskinan yang berlangsung lama. Kaum miskin mengalami keterbatasan dalam hal pendidikan, keterampilan, sarana usaha serta modal usaha. Tawaran kredit Usaha Mikro Kecil dan Menengah (UMKM) dari pengusaha dan perbankan sulit diakses oleh kaum miskin, karena keterbatasan kemampuan dan asset yang dimiliki. Pemerintah dalam hal ini dinas sosial berusaha menemukan pola yang efektif agar kaum miskin dapat memperoleh akses modal usaha tanpa agunan dengan tetap mendorong tanggungjawab bersama melalui pola terpadu Kelompok Usaha Bersama (KUBE).

Kecamatan Ploso dengan empat desa yang dipilih ( Genenganjasem, Pandanblole, Gebangbunder dan Gedong Omboh ) dipilih oleh dinas ketahanan pangan, karena daerah tersebut ditetapkan sebagai daerah krisis pangan, hal tersebut terjadi karena banyak sekali para penduduk yang menjual tanah pertanian di tempat tersebut menjadi lahan yang digunakan untuk mendirikan perumahan sehingga luas tanah pertanian semakin sempit dan beralih fungsi menjadi perumahan yang dikawatirkan dengan adanya banyanya tanah yang dijual, maka akan membuat lahan pertanian semakin sempit sehingga akan mempengaruhi produksi dari tanaman pangan semisal padi dan jagung.

Khalayak sasaran yang strategis dalam kegiatan ini adalah masyarakat yang tergolong dalam Keluarga Menuju Sejahtera (KMS) yang berada di desa pandanblole Jumlah peserta pelatihan sebanyak 20 orang terdiri atas pria dan wanita. Dari hasil pantauan awal tim penulis, diketahui bahwa ada beberapa permasalahan yang dihadapi kelompok sasaran yaitu: 1) Peluang usaha yang ada relatif terbatas, 2) Belum optimalnya usaha ekomomi produktif dan 3) Keterbatasan akses pasar bagi kelompok usaha. Karena itu, penulis berupaya memberikan pelatihan kepada masyarakat sasaran yaitu yang berada di Desa Pandan Blole, agar bisa berdaya dan meningkatkan perekonomian melalui Kelompok Usaha Bersama (Kube).

\section{Landasan Teori}

Todaro (1983) mengartikan pembangunan merupakan proses multi dimensi yang mencakup perubahan-perubahan penting dalam struktur sosial,sikap-sikap rakyat dan lembaga-lembaga nasional. Pada pelaksanaannya konsep pembangunan tersebut masih jauh dari kenyataan. Berbagai temuan empirik menunjukkan masih terjadi marjinalisasi kehidupan masyarakat terutama kaum miskin baik di perkotaan maupun perdesaan.

Pada hakekatnya kemiskinan menurut Moeljarto (1994) tidak hanya persoalan kesejahteraan tetapi ada enam alasan yang dapat dijadikan sebagai dasar orang dikatakan miskin, yaitu: 1) Kemiskinan adalah masalah kerentanan; 2) Kemiskinan berarti tertutupnya akses kepada berbagai peluang bagi mereka untuk berpartisipasi dalam proses produksi, atau terperangkap pada hubungan produksi yang ekspotatif dengan imbalan yang rendah; 3) Kemiskinan adalah masalah ketidakpercayaan, perasaan impotensi emosional dan sosial atas keputusan yang dilakukan elit birokrasi dalam berbagai tingkat; 4) Kemisknan berarti juga menghabiskan semua atau sebagian 
besar penghasilan untuk konsumsi pangan dalam kuantitas dan kualitas yang terbatas sehingga konsumsi gizi rendah yang berakibat pada produksi yang rendah; 5) Kemiskinan ditandai dengan rendahnya rasio, ketergantungan karena besarnya tanggungan keluarga yang berakibat rendahnya konsumsi sehingga berpengaruh pada kecerdasan; dan 6) Kemiskinan juga terefleksi pada budaya yang diwariskan dari satu generasi ke generasi lain.

Alfian, Tan dan Soemardjan (1980) mengatakan ada dua kategori pengukuran tingkat kemiskinan yaitu kemiskinan absolut dan kemiskinan relatif. Kemiskinan absout merupakan suatu kondisi dimana tingkat pendapatan seseorang tidak cukup untuk memenuhi kebutuhan pokok seperti pangan, sandang, papan, kesehatan dan pendidikan. Sedangkan kemiskinan relatif adalah penghitungan kemiskinan berdasarkan, proporsi distribusi pendapatan dalam suatu daerah. Kemiskinan ini dikatakan relatif karena lebih berkaitan dengan distribusi pendapatan lapisan sosial

Dengan demikian, membicarakan kemiskinan merupakan suatu persoalan yang kompleks dan perlu didekati dari berbagai aspek, namun untuk memahami kemiskinan yang obyektif ada indikator yang dapat menjadi patokan pengukuran. Bank Dunia menetapkan garis batas kemiskinan \$US 50 per kapita tahun.

Pengembangan Usaha Ekonomi Produktif (UEP) dan Usaha Kesejahteraan Sosial (UKS) melalui Kelompok Usaha Bersama (Kube) bagi kaum miskin merupakan salah satu program yang di usulkan oleh STIE PGRI DEWANTARA bekerja sama dengan Dinas Ketahanan Pangan Kab Jombang untuk mengatasi adanya kemiskinan dan krisis rawan pangan, dengan mengubah cara pandang penduduk sekitar mengenai pentingnnya tanaman pangan serta bagaimana mengolah produk pangan tersebut sehingga memiliki nilai jual dan akan memberikan dampak pada peningkatan kesejahteraan masyarakat.

\section{B. METODE PELAKSANAAN KEGIATAN}

Untuk mengatasi permasalahan sebagaimana yang telah disebutkan diatas, maka penulis melakukan berbagai kegiatan yang dimulai pada bulan April 2016 hingga Agustus 2017, yaitu:

1. Memberi pemahaman mengenai kewirausahaan sebagai modal awal dalam mengembangkan usaha. Bentuk kegiatannya adalah pelatihan motivasi berusaha dan kewirausahaan.

2. Mengembangkan usaha ekonomi produktif dalam bentuk Kelompok Usaha Bersama yang didasarkan pada potensi kelompok.

Proses pelatihan dimulai dengan penemuan produk ungulan, pengelolaaan sampai proses pemasaran dan ijin usaha, adapun penjelasan lebih rinci sebagai berikut:

1. Seminar membuka wawasan seputar wirausaha (April sampai Juni )

2. Pelatihan penemuan usaha berbasis kearifan lokal ( April sampai Juni )

3. Pelatihan pengolahan produk ( dilakukan Juli sampai September )

4. Pelatihan design produk ( dilakukan Oktober sampai Desember)

5. Pelatihan pemasaran produk ( dilakukan pada bulan Januari sampai Maret )

6. Pelatihan perijinan produk ( dilakukan April sampai Juni )

7. Pelatihan manajemen usaha dalam hal keuangan (Juli sampai Agustus )

Kegiatan ini pelatihan dan pendampingan ini melibatkan berbagai pihak dalam pelaksanaannya, antara lain Kepala Desa Pandanblole sebagai pihak yang menyediakan saran dan prasarana untuk kegiatan seminar dan workshop serta di dukung pula oleh Dinas Ketahangan Pangan yang diharapkan akan dapat memberi dukungan melalui 
program-program yang terkait dengan pemberdayaan masyarakat miskin melalui pembentukan Kube (Kelompok Usaha Bersama)

\section{HASIL KEGIATAN}

Masyarakat yang berpartisipasi adalah seluruh warga desa kecamatan Ploso yang berada di balai desa Panda blole. Proses pelatihan yang telah dilakukan adalah ( Seminar membuka wawasan seputar wirausaha (April sampai Juni 2016), Pelatihan penemuan usaha berbasis kearifan lokal (April sampai Juni 2016), Pelatihan pengolahan produk ( dilakukan Juli sampai September 2016), Pelatihan design produk (dilakukan Oktober sampai Desember 2016 ), Pelatihan pemasaran produk ( dilakukan pada bulan Januari sampai Maret 2017), Pelatihan perijinan produk ( dilakukan April sampai Juni 2017) dan Pelatihan manajemen usaha dalam hal keuangan (Juli sampai Agustus 2017). Seluruh kegiatan dapat terlaksana dengan baik dan peserta pelatihan bisa mengikuti dan menyerap pengetahuan yang telah disampaikan tim pelatih.

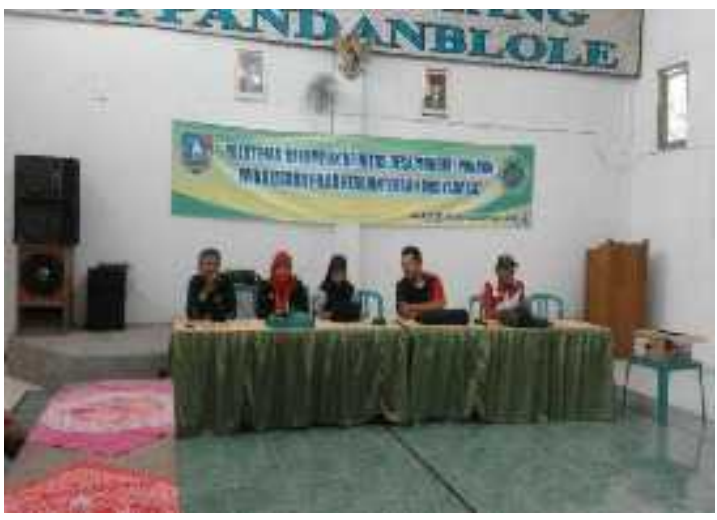

Gambar 1: seminar wirausaha

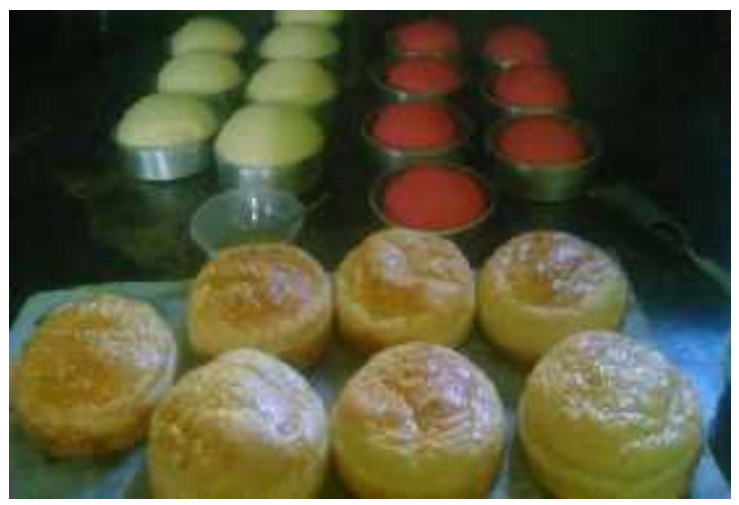

Gambar 2: pelatihan usaha berbasis bahan lokal

\section{PENUTUP}

Kegiatan pengabidan masyarakat melalui pelatihan dan pendampingan di Desa Pandan Blole Kecamatan Ploso bisa terlaksana dengan baik. Hal ini terlihat dari antusias peserta pelatihan serta bersedia menciptakan produk berbahan dasar local (labu kuning) serta memasarkanya diluar wilayah Pandan Blole/

Namun demikian, kegiatan yang sudah diawali oleh tim masih perlu pembinaan berkelanjutan dari berbagai pihak agar masyarakat binaan semakin meningkatkan produksinya serta memasarkannya dalam jumlah besar, dengan media pemasaran yang semakin beragam dan modern seperti pemasaran secara daring (online).

\section{BIBLIOGRAFI}

Allan, Tan, M.G., dan Soemardjan, S, 1980, Kemiskinan Struktural, Suatu Bunga Rampai.Jakarta:YIIS

Ellis, G.F.R. 1984. The Dimension of Poverty dalam Social Indicator Research

Esmara, H. 1986. Perencanaan dan Pembangunan di Indonesia, Jakarta: Gramedia Kempton, J. 1995. Human Resource Management and Development. London:MacMillanPress Ltd

Moeljanto, T. 1996. Pembangunan, Dilema dan Tantangan. Yogyakarta: Pustaka Pelajar Todaro, P. 1983. Pembangunan Ekonomi di Dunia Ketiga, Jilid I. Jakarta: Ghalia Indonesia 